\author{
Alicja Korzeniecka-Bondar \\ Uniwersytet w Białymstoku \\ e-mail: alibon@uwb.edu.pl ORCID: oooo-ooo3-1145-2996
}

\title{
Sprawozdanie z Seminarium naukowego (online) „Opowieść", 05 marca 2021
}

05 marca 2021 odbyło się seminarium naukowe poświęcone OPOWIEŚCI, które zorganizowały: Komisja ds. Rozwoju Młodych Naukowców Komitetu Nauk Pedagogicznych PAN oraz Redakcja czasopisma „Parezja. Czasopismo Forum Młodych Pedagogów przy Komitecie Nauk Pedagogicznych PAN”. Inicjatorami spotkania byli młodzi naukowcy: pedagog i prawnik - dr Aleksander Cywiński (Uniwersytet Szczeciński) oraz socjolodzy - dr Kalina Kukiełko-Rogozińska (Uniwersytet Szczeciński) i dr Krzysztof Tomanek (Uniwersytet Jagielloński).

Wszystkich przybyłych na spotkanie akademików, badaczy opowieści, doktorantów i studentów, przywitała dr hab. Alicja Korzeniecka-Bondar, redaktor naczelna Parezji. Otwarcia seminarium dokonała i inspirującego wprowadzenia w problematykę opowieści i jej roli w naukach społecznych dokonała prof. dr hab. Maria Czerepaniak-Walczak, Przewodnicząca Komisji ds. Rozwoju Młodych Naukowców Komitetu Nauk Pedagogicznych PAN. Dr hab. Maciej Kowalewski, prof. US, Dyrektor Instytutu Socjologii Uniwersytet Szczecińskiego wskazał na genezę problematyką opowieści oraz jej znaczenie w socjologii. O idei zorganizowania seminarium opowiedział dr Aleksander Cywiński, a dr Krzysztof Tomanek ukazał własne źródła zainteresowania opowieścią ( $\mathrm{w}$ tym potencjału opowieści budowanych na danych empirycznych).

Doświadczenia pandemii koronawirusa stały się kluczowym wątkiem jednej z sesji wystąpień, w trakcie której głos zabrali: członkowie i członkinie zespołu badającego doświadczenia studentów i nauczycieli akademickich w czasie pandemii: dr hab. Elżbieta Perzycka, prof. US, studentka Wiktoria Orzechowska (US) - Listy z pandemii - dwugłos akademicki - oraz dr Krzysztof Łuszczek (US) - Dylematy autoprezentacji - jezzyk ludzkiej twarzy. Te interesujące wypowiedzi (bazujące na autoetnografii), odsłaniające prze- 
miany w procesie uczenia się i interakcjach spowodowanych zdalną edukacją, stały się inspiracją do dyskusji dotyczącej zdalnej edukacji oraz potencjalnych konsekwencji doświadczeń „covidowych” dla przyszłego funkcjonowania szkoły. Mgr Jolanta Ambrożewicz (UwB), na podstawie badań własnych stworzyła Opowieść o doświadczaniu wsparcia w dobie kryzysu. Doświadczenia przedsiębiorców zrzeszonych $w$ organizacjach biznesowych, ukazując znaczenie relacji, wzajemnego zaufania i zaangażowania $\mathrm{w}$ radzeniu $\mathrm{z}$ trudnościami wynikającymi dla biznesmenów z pandemii.

Super kraj, to tytuł wystąpienia mgr. Patryka Słowińskiego (Zachodniopomorski Uniwersytet Technologiczny), który ukazał potencjał komunikacyjny oraz siłę przekazu murali umieszczanych w przestrzeni miasta. Ukazując historię muralu związanego ze strajkiem kobiet, zwracał uwagę na potrzebę odwagi i zaangażowania, co wybrzmiało także w wypowiedzi dr. Aleksandra Cywińskiego, Opowieść o tym jak się stałem politycznym aktywistą. To doświadczenia stało się dla samego zainteresowanego źródłem licznych zadziwień i inspiracji do refleksji (nie tylko na temat polityki). Dr Przemysław Łonyszyn (Instytut Studiów Regionalnych w Szczecinie), snując Opowieść o opowieści zastanawiat sie „jak ratować historię przed zapomnieniem?”. Prezentując własne doświadczenia z prowadzenia wywiadów z osobami dojrzałymi posiadającymi traumatyczne doświadczenia, np. związane z wywózką na Sybir zainspirował do dyskusji o roli pamięci autobiograficznej, znaczeniu przekazu międzygeneracyjnego oraz etycznym wymiarze przyjmowania „daru opowieści drugiego człowieka”. W długiej, inspirującej dyskusji podkreślano potrzebę stwarzania w szkole i innych środowiskach edukacyjnych warunków do „snucia opowieści”, nieśpiesznego opowiadania a tym samym kształtowania umiejętności słuchania drugiego człowieka.

Dr Kalina Kukiełko-Rogozińska (US), w wystąpieniu Historie, które możemy na siebie założyć. Leanne Prain i jej tekstylny storytelling ukazała, jak wzajemnie przenikają się rzeczy, kultura i edukacja; jakie interesujące, wielowymiarowe opowieści zawarte mogą być na przykład w kurtce oraz, że „życie ubrań" (ich powstawania, przeznaczenie, wykorzystywanie, itd.) może mieć polityczne znaczenie. Dr Michał Paluch (UKSW), w wypowiedzi Podmiot liryczny jako przedmiot badań ginetyki, uwrażliwiał na wewnętrzne przeżycia nauczyciela i ucznia uwikłanych wzajemnie w doznanie uniesienia i olśnienia poznawczego. Upominał się o głęboko egzystencjalny sens nauczania jako sposobu uczestnictwa (bytowania) w świecie oraz troskę o świat wewnętrzny i jego otoczenia jako doświadczenie intelektualno - duchowe. W namysł o jakości spotkania nauczyciela z uczniami wpisała się studentka Marta Makarewicz (Studenckie Koło Naukowe Socjologii Edukacji, Uniwersytet w Białym- 
stoku), która opowiadała $O$ (nie)docenianiu kręgu jako przestrzeni swobodnej narracji dziecięcej. Krąg z jego nieantagonizującym kształtem, podmiotowym i równym traktowaniem stwarza możliwość dialogu, spotkania i tworzenia narracji przez dziecko. Ponadto, daje sposobność do diagnozowania potrzeb dzieci oraz reagowania na bieżące, codzienne zdarzenia. O trudnościach badania i opowiadania o codziennych (zwyczajnych i odświętnych) doświadczeniach dziejących się w budynku Collegium Maius mówiła dr Żaneta Kubic (Muzeum Uniwersytetu Jagiellońskiego Collegium Maius), W pogoni za symetria - na tropach opowieści w narracji o Collegium Maius. Prezentując tytułową „pogoń za symetrią” odsłaniała własne dylematy jako badaczki i autorki tekstów naukowych o Collegium Maius; popularyzatorki wiedzy o tym niezwykłym, zasobnym w opowieści miejscu. Te inspirujące referaty ukazały kolejne argumenty wskazujące na potrzebę opowieści zarówno w życiu, jak i nauce. Mamy nadzieję na jej kolejne odsłony!

W dyskusji uczestnicy spotkania, w tym członkowie i członkinie Komisji ds. Rozwoju Młodych Naukowców, wskazali nowe tropy ontologiczne i epistemologiczne odnośnie do opowieści jako zjawiska kulturowego ze szczególnym uwzględnieniem jej kontekstów pedagogicznych. 